\title{
ZAKAT SEBAGAI PENGURANG PAJAK DALAM HUKUM INDONESIA
}

\author{
(Studi Historis Regulasi tentang Zakat sebagai Pengurang Pajak) \\ Muhammad Redha Anshari \\ Dosen IAIN Palangka Raya \\ Email : m.redhaanshari@gmail.com
}

\begin{abstract}
ABSTRAK
Zakat dan pajak, meskipun keduanya merupakan kewajiban dalam bidang harta, namun keduanya mempunyai falsafah yang khusus dan keduanya berbeda sifat dan asasnya, berbeda sumbernya, sasaran, bagian serta kadarnya, di samping berbeda pula mengenai prinsip, tujuan, dan jaminannya, tetapi ada pula sisi kesamaannya.

Zakat dan pajak merupakan dua hal yang dapat ditinjau dari aspek semantik dan tujuan memliki perbedaan. Pajak merupakan sebuah keharusan yang telah ditetapkan oleh negara sebagai kewajiban warga negara. Pembayaran pajak dengan berbagai jenis dan ragamnya adalah murni urusan duniawi yang tidak terkait dengan dimensi spritual dan dilakukan oleh warga negara (muslim maupun non muslim).

Dalam sejarahnya ketentuan atau regulasi yang mengatur tentang zakat yang menjadi pengurang pajak dalam hokum Indonesia terbagi menjadi 2 periode, yaitu : Pertama, Periode undang-undang tentang pengelolaan zakat no. 38 tahun 1999. Kedua, Periode undang-undang tentang pengelolaan zakat no. 23 tahun 2011.

Dari kedua periode tersebut terdapat beberapa kesamaan serta terdapat juga beberapa perbedaan yang mengatur tentang mekanisme zakat sebagai pengurang pajak dalam hokum Indonesia.
\end{abstract}

Kata Kunci: Zakat, Pajak, Zakat di Indonesia, Zakat Pengurang Pajak

\begin{abstract}
Zakat and tax, although both are liabilities in the field of assets, but both have a specific philosophy and both differ in nature and principle, different sources, objectives, parts and levels, in addition to different principles, objectives, and guarantees, but there are also sides similarity.

Zakat and tax are two things that can be viewed from the semantic aspect and the goal has differences. Tax is a necessity that has been set by the state as a citizen obligation. Payment of taxes with various types and varieties is purely worldly affairs that are not related to the spiritual dimension and carried out by citizens (Muslim or non-Muslim).

In its history the provisions or regulations governing zakat which are tax deductible in Indonesian law are divided into 2 periods, namely: First, Period of undang-undang tentang pengelolaan zakat no. 38 tahun 1999. Second, Period of undang-undang tentang pengelolaan zakat no. 23 tahun 2011. From these two periods there are some similarities and there are also some differences that govern the mechanism of zakat as a tax deduction in Indonesian law.
\end{abstract}

Keywords: Zakat , Zakat in Indonesia, Tax Deduction Zakat 


\section{Pendahuluan}

Zakat dan pajak, meskipun keduanya merupakan kewajiban dalam bidang harta, namun keduanya mempunyai falsafah yang khusus dan keduanya berbeda sifat dan asasnya, berbeda sumbernya, sasaran, bagian serta kadarnya, di samping berbeda pula mengenai prinsip, tujuan, dan jaminannya, tetapi ada pula sisi kesamaannya.

Zakat dan pajak merupakan dua hal yang dapat ditinjau dari aspek semantik dan tujuan memliki perbedaan. Pajak merupakan sebuah keharusan yang telah ditetapkan oleh negara sebagai kewajiban warga negara. Pembayaran pajak dengan berbagai jenis dan ragamnya adalah murni urusan duniawi yang tidak terkait dengan dimensi spritual dan dilakukan oleh warga negara (muslim maupun non muslim).

Pengeluaran zakat menggambarkan dua sisi yang secara sinergis saling menyatu yaitu kepentingan jangka pendek (kebutuhan ekonomi dan duniawi) yang berimplikasi secara lebih luas pada kepentingan jangka panjang (kepentingan spiritual/ukhrawi) individu muzakki.

Sebagaimana telah diketahui, bahwa yang berkenaan dengan zakat dan pajak telah diundang-undangkan oleh pemerintah RI, yakni Undang-undang Nomor 23 Tahun 2011 tentang Pengeloaan Zakat dan Undang-undang Nomor 36 Tahun 2008 tentang Pajak Penghasilan. Ketentuan zakat sebagai pengurang pajak pertama kali muncul dalam Undang-undang No. 38 Tahun 1999 tentang Pengelolaan Zakat. Dalam undang-undang tersebut disebutkan: "zakat yang telah dibayarkan kepada badan amil zakat atau lembaga amil zakat dikurangkan dari laba/pendapatan sisa kena pajak dari wajib pajak yang bersangkutan sesuai dengan peraturan perundang-undangan yang berlaku".

Dalam penjelasan undang-undang tersebut terdapat uraian yang memperjelas bunyi ayat tersebut, yakni: "pengurangan zakat dari laba/pendapatan sisa kena pajak dimaksudkan agar wajib pajak tidak terkena beban ganda, yakni kewajiban membayar pajak dan zakat". Kesadaran membayar zakat dapat memacu kesadaran membayar pajak. Zakat sebagai pengurang pajak, memang lebih ditujukan kepada institusi meski perorangan juga sangat dimungkinkan. Hal itu dikarenakan, institusi yang biasanya memiliki laba bersih relatif besar.

Latar belakang dari pengurangan ini dijelaskan dalam penjelasan Pasal 14 ayat (3) UU No. 38 Tahun 1999 bahwa pengurangan zakat dari laba/pendapatan sisa kena pajak adalah dimaksudkan agar wajib pajak tidak terkena beban ganda, yakni kewajiban membayar zakat dan pajak. Ketentuan ini masih diatur dalam UU zakat yang terbaru yakni dalam Pasal 22 UU 23/2011: "Zakat yang dibayarkan oleh muzaki kepada BAZNAS atau LAZ dikurangkan dari penghasilan kena pajak” Ketentuan serupa ditegaskan pula dalam Pasal 9 ayat (1) UU Pajak Penghasilan. Selain itu, Pasal 1 ayat (1) PP No. 60 Tahun 2010 tentang Zakat atau Sumbangan Keagamaan yang Sifatnya Wajib yang Boleh Dikurangkan dari Penghasilan Bruto juga menentukan:

"Zakat atau sumbangan keagamaan yang sifatnya wajib yang dapat dikurangkan dari penghasilan bruto meliputi:

a) zakat atas penghasilan yang dibayarkan oleh Wajib Pajak orang 
pribadi pemeluk agama Islam dan/atau oleh Wajib Pajak badan dalam negeri yang dimiliki oleh pemeluk agama Islam kepada badan amil zakat atau lembaga amil zakat yang dibentuk atau disahkan oleh Pemerintah; atau

b) sumbangan keagamaan yang sifatnya wajib bagi Wajib Pajak orang pribadi pemeluk agama selain agama Islam dan/atau oleh Wajib Pajak badan dalam negeri yang dimiliki oleh pemeluk agama selain agama Islam, yang diakui di Indonesia yang dibayarkan kepada lembaga keagamaan yang dibentuk atau disahkan oleh Pemerintah."

Dari paparan singkat latar belakang masalah diatas, maka rumusan masalah yang hendak diteliti adalah Bagaimana sejarah pengaturan zakat sebagai pengurang pajak dalam hokum indonesia?

\section{Landasan Teori}

\section{a. Teori tentang Pajak}

Menurut Adrian Sutedi pajak dari perspektif ekonomi dipahami sebagai beralihnya sumber daya dari sektor privat kepada sektor publik. Pemahaman ini memberkan gambaran bahwa adanya pajak menyebabkan dua situasi menjadi berubah. Pertama, berkurangnya kemampuan individu dalam menguasai sumber daya untuk kepentingan penguasaan barang dan jasa. Kedua, bertambahnya kemampuan keuangan negara dalam penyediaan barang dan jasa publik yang merupakan kebutuhan masyarakat.

Sementara pemahaman pajak dari perspektif hukum menurut Soemitro merupakan suatu perikatan yang timbul karena adanya undang-undang yang menyebabkan timbulnya kewajiban warga negara untuk menyetorkan sejumlah penghasilan tertentu kepada negara, negara mempunyai kekuatan untuk memaksa, dan uang pajak tersebut harus digunakan untuk penyelenggaraan pemerintahan. Dari pendekatan hukum ini memperlihatkan bahwa pajak yang dipungut harus berdasarkan undang-undang sehingga menjamin adanya kepastian hukum, baik bagi fiksus sebagai pengumpul pajak maupun wajib pajak sebagai pembayar pajak.

Secara umum pajak adalah iuran rakyat kepada kas negara berdasarkan undang-undang, sehingga dapat dipaksakan dengan tiada mendapat balas jasa secara langsung. Pajak dipungut penguasa berdasarkan norma-norma hukum untuk menutupi biaya produksi barang dan jasa kolektif untuk mencapai kesejahteraan umum.

Menurut Mar'ie Muhammad penetapan objek pajak dalam suatu undang-undang pajak harus memenuhi kriteria yaitu:

1) Bersifat pajak dan bukan retribusi

2) Objek dan dasar pengenaan pajak tidak bertentangan dengan kepentingan umum

3) Potensinya memadai

4) Tidak memberikan dampak ekonomi yang negatif.

Merujuk kepada konsepsi negara hukum, maka penetapan objek pajak dalam suatu undang-undang, harus memenuhi kriteria dan syarat tertentu yang disebut tatbestand. Menurut Rahmat Soemitro tatbestand diartikan sebagai sesuatu yang dikenakan pajak disebabkan karena adanya unsur keadaan, perbuatan atau peristiwa.

Menurut adam smith terdapat 4 (empat) syarat utama yang harus dipenuhi 
dalam rangka pemungutan pajak terhadap suatu objek pajak yaitu:

a. Equality dan equity

Dalam suatu negara tidak diperbolehkan mengadakan diskriminasi di antara wajib pajak. Pengenaan pajak terhadap subjek hendaknya dilakukan seimbang sesuai dengan kemampuannya.

b. Certainty

Pajak yang harus dibayar oleh wajib pajak harus pasti untuk menjadmin adanya kepastian hukum, baik mengenai subjek, objek, besarnya pajak, dan saat pembayarannya. Menurut Rochmat Soemitro syarat certainty atau kepastian hukum, memberikan gambaran tentang perumusan norma hukum dalam suatu undang-undang pajak, yakni harus bersifat jelas, tegas dan tidak mengandung arti ganda. Guna memenuhi syarat certainty, dalam rangka penetapan objek, maka pembentukan undangundang pajak harus memperhatikan asas-asas pembentukan undangundang.

c. Convinience of payment

Pajak hendaknya dipungut pada saat paling tepat/baik bagi para wajib pajak

\section{d. Economics of collection}

Sebagai fungsi budgeter, pajak juga digunakan sebagai alat untuk menentukan politik perekonomian, tidak mungkin suatu negara menghendaki merosotnya kehidupan ekonomi masyarakat, karena itu pemungutan pajak sebagai berikut:
- Harus diusahakan supaya jangan sampai menghambat lancarnya produksi dan perdagangan.

- Harus diusahakan supaya jangan menghalang-halangi rakyat dalam usahanya menuju kebahagiaan dan jangan sampai merugikan kepentingan umum.

\section{b. Teori kewajiban zakat dalam perspektif ekonomi Islam}

Gazi Inayah berpendapat Sumber transaksi hukum keuangan adalah pemikiran hukum, sedangkan standarnya adalah pemerintahan modern, terkadang transaksi keuangan itu berdasarkan pada al-Quran dan al-Hadis, standarnya adalah kemaslahatan rohani, pelopornya bukan pemerintahan, tetapi hak dan kewajiban bagi masyarakat sebagai realisasi kemaslahatan pemerintahan Islam.

Sesungguhnya kewajiban zakat dasarnya adalah hukum illahi, yang bersumber pada al-Quran dan al-Hadis, aplikasinya adalah merealisasikan hukum dalam al-Quran dan al-Hadis secara sempurna dan benar melalui pemerintahan sebagai pemungut zakat dari masyarakat. Sedangkan realisasi dari hukum yang tertulis dalam al-Quran dan al-Hadis adalah bukti pelaksanaan dan tanggung jawab terhadap hukum Islam, di dalamnya ada hak kepemimpinan sebagai warga masyarakat dan sebagai mukallaf yang terpanggil untuk merealisasikan prinsipprinsip solidaritas sosial dengan mewajibkan masyarakat untuk membayar zakat sebagai saham dalam mengemban beban masyarakat luas.

Menurut Gazi inayah dalam bukunya Al-Iqtisad al-Islami az-Zakah wa ad-Daribah ada beberapa teori mengenai dasar pengenaan zakat terhadap muslim, yaitu: 
a. Teori khilafah

Dasar teori ini adalah bahwa semua harta itu milik Allah sedangkan manusia hanyalah sebagai pengemban saja, maka dia harus mampu mengemban beban khilafah ini, misalnya membelanjakan harta di jalan Allah, infak dan lainlain.

Allah berfirman dalam surah an-Najm ayat 31 :

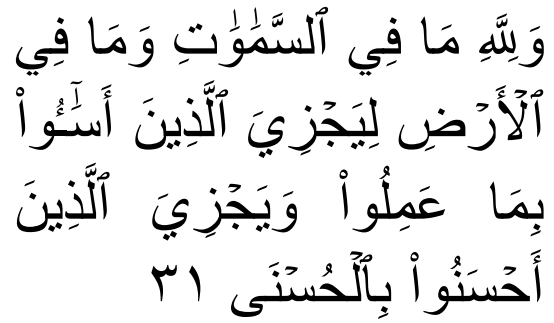

Juga pada surah Thaha ayat 6 :

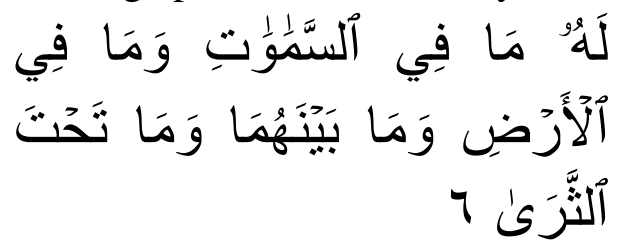

Semua yang ada dijagad ini adalah milik Allah bahkan sampai pada debu kecil di langit dan di bumi. Semua kenikmatan yang diberikan Allah kepada hamba-Nya adalah anugrah dari-Nya dan Allah menitipkan rizki itu kepada hamba-Nya, sebagai orang yang terpercaya dalam memlihara rizki Allah, mensyukurinya dengan ketaatan.

Allah adalah zat pemberi rizki dan pencabut rizki. Sedangkan hamba hanyalah dapat membelanjakan harta milik Allah sebab seorang hamba hanyalah wakil yang membelanjakan harta. Wakil itu menduduki tempat yang diwakilkan dengan ketaatan, membelanjakan dan infak, bila tidak demikian maka ia mendapat kutukan Allah.

Imam ar-Razi berkata dalam tafsirnya: Sesungguhnya para fakir miskin itu keluarga Allah, sedangkan orang kaya itu ibarat pemilik harta yang dimilikio manusia itu adalah harta allah, maka tidak dibenarkan seorang konglomerat berkata kepada pembantunya: berikan harta itu kepada kelompok orang dari keluargaku”.

Apabila orang kaya itu kikir dengan harta yang diberikan Allah kepadanya terhadap fakir miskin, maka dia layak mendapat kecaman dari Allah. Dalam hadist Qudsi dijelaskan bahwa allah berfirman: "Harta adalah kekayaan-Ku, fakir miskin adalah keluarga-Ku, orang kaya adalah para wakil-Ku, apabila wakil-wakl-Ku itu kikir terhadap keluarga-Ku, maka Aku akan memberikan balasan kepada mereka dan Aku tidak akan memperdulikan mereka".

b. Teori beban umum

Teori ini muncul atas dasar bahwa hak Allah dalam menetapkan beban terhadap hambanya dan sesuai dengan 
kehendak-Nya, seperti ibadah fisik atau ibadah maliyah yang murni hanya untuk Allah, memuji kepada-Nya serta taat kepada-Nya. Allah berfirman dalam surah az-Zariyat ayat 56 :

עִ وَأَلِْنسنَ
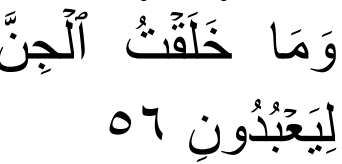

Asas

kehidupan

manusia adalah ibadah dan ibadah adalah taklif (beban). Barang siapa taat, maka ia selamat dan barang siapa tidak taat, maka ia akan durhaka. Allah berfirman dalam surah an-Najm surah 31:

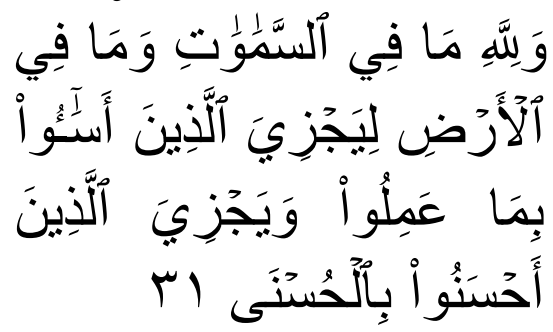

Manusia akan dimintai pertanggungjawaban amalnya, baik amal yang baik dan buruk. Manusia itu mukallaf dan dia diciptakan bukan untuk mainmain. Barang siapa yang menjalankan beban tersebut, maka ia berhak mendapat jaminan dari Allah, barang siapa yang tidak siap maka ia akan tergadai.

c. Teori jaminan sosial

Dasar teori ini adalah
hak masyarakat dalam
mengelola hartanya. Sebagai
anggota masyarakat mereka
mempunyai hak yang harus
dilindungi, dibantu apa yang

mereka lakukan, diringankan bebannya dan diayomi, bukan karena belas kasihan. Warga masyarakat harus memiliki solidaritas, saling membantu. Hal ini karena manusia adalah makhluk sosial yang tidak dapat hidup sendirian, atau keluar dari masyarakat. Manusia dapat bekerja dan mendapat kemudahan karena bantuan orang lain dan harta yang diperolehnya juga dari masyarakat. Oleh karena itu masyarakat tidak boleh mengeluarkan hartanya kecuali pada hal yang bermanfaat bagi kesejahteraan mereka, setiap pemborosan belanja akan berdampak negatif bagi masyarakat. Islam mengakui teori ini dan menghubungkannya dengan harta individu dan masyarakat serta sistem pembelanjaan harta.

Allah berfirman dalam surah an-Nisa ayat 5:
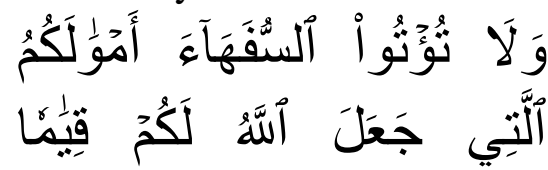

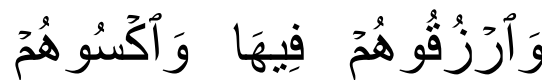

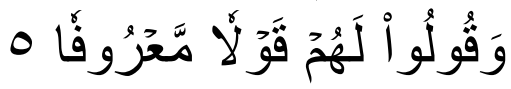

Rasa memiliki harta bersama antara individu dengan masayrakat adalah untuk menghindari sikap negatif dalam membelanjakan harta. 
al-Isra ayat 27:

Allah berfirman dalam surah

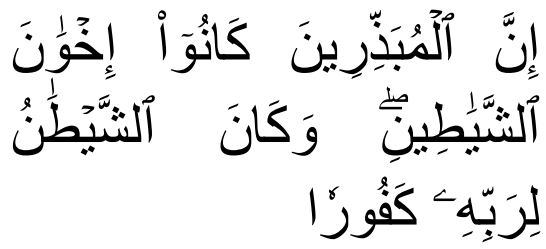

Nash

al-Quran

menyambung

dan

mempersatukan

harta

masyarakat yang diringkas

menjadi amwalakum dan kata

anfusukum ini untuk

memperkuat bahwa harta

sebgaian orang itu juga harta orang lain, sebab kata jiwa itu artinya satu dan nash al-Quran tidak mengatakan sebagian harta kalian, kata ini juga untuk memperkuat bahwa masyarakat muslim itu satu kesatuan dan dalam kesatuan nini mereka hidup saling membantu dan bersikap solidaritas, tanpa merampas hak yang telah ditentukan.

d. Teori persaudaraan

Teori ini muncul berdasarkan kaidah-kaidah persaudaraan dalam keyakinan dan kemanusiaan, kaidah persaudaraan dalam keyakinan itu adalah sistem rohani yang saling mengkiat, mendarah daging, belas kasih dan solidaritas antara saudara dalam masyarakat insani yang satu. Allah berfirman dalam surah al-Hujurat ayat 10:

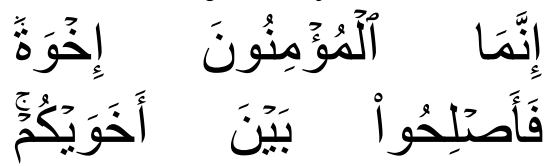

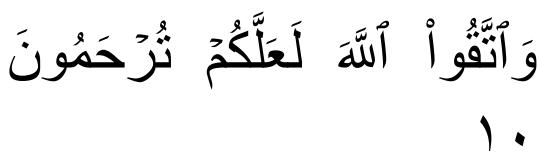

Nabi telah memberikan gambaran tentang persaudaraan, yaitu bagaikan bangunan yang kokoh, setiap anggota tubuh mempunyai hak kepada yang lain dalam menjaga keselamatan. Rasulullah bersabda: "orang mukmim terhadap mukmin lain itu seperti bangunan yang saling memperkuat sebahagiannya'. Rasullah juga bersabda: "perumpamaan orang mukmin dalam kasih sayang dan kelembutannya adalah bagaikan satu jasad, apabila anggota yang merasa sakit, maka sebagian lain merasa sakit panas dan tidak bisa tidur di waktu malam".

Hadis Nabi telah mengaitkan antara iman dan kewajiban persaudaran yang saling membantu, menolong dan berinfak. Rasulullah SAW bersabda; "tidak beriman sempurna kepadaku orang yang selalu kenyang sedangkan tetangganya dalam kelaparan dan dia mengetahuinya.

Kaidah-kaidah

persaudaraan manusia merupakan suatu sistem yang berdasarkan wahyu yang saling terkait, mendarah daging dan solidaritas, sebab manusia semuanya bersaudara yang 
berasal dari satu manusia yaitu adam, Allah berfirman dalam surah al-Hujurat ayat 13:

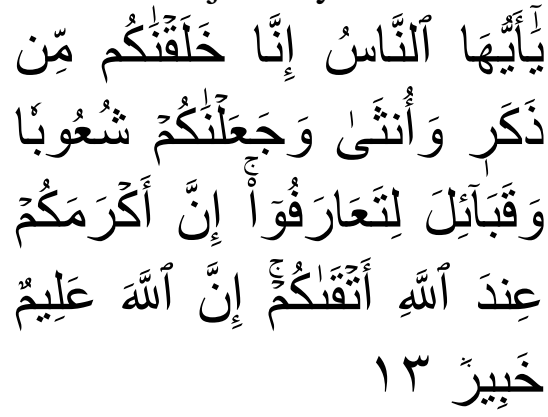

Islam menjelaskan

kaidah-kaidah interaksi manusia, Islam membangun hubungan manusia dengan yang lain maka kemudian disyariatkan zakat adalah untuk merealisasikan hubungan manusia supaya saling tolong menolong, menahan kesengsaraan, memenuhi kebutuhan orang miskin dan lain-lain.

\section{Metode Penelitian}

Menurut Peter Mahmud Marzuki Penelitian hukum adalah suatu proses untuk menemukan aturan hukum, prinsipprinsip hukum maupun doktrin-doktrin hukum guna menjawab isu hukum yang dihadapi.

\section{Jenis Penelitian}

Menurut Soerjono Soekanto Penelitian yang dilakukan adalah jenis penelitian hukum normatif. Cakupan penelitian meliputi penelitian terhadap azas-azas hukum, penelitian terhadap sistematika hukum, penelitian terhadap taraf sinkronisasi hukum, yang keseluruhannya tergabung dalam pendekatan konseptual penelitian.

\section{Pendekatan Penelitian}

Penelitian ini menggunakan 3 pendekatan, yaitu :

a. Pendekatan yuridis normatif, yaitu pendekatan dalam memahami hukum dari kaidah normatif aturan hukum tersebut beserta penjelasannya;

b. Pendekatan kebijakan, yakni pendekatan dalam pembuatan peraturan perundang-undangan yang berorientasi kepada tujuan yang hendak dicapai;

c. Pendekatan ekonomi atas hukum (analysis economic of law). Hal ini digunakan atas dasar bahwa ilmu hukum merupakan ilmu yang berusaha untuk menyesuaikan dengan hal lain agar dapat menjangkau ruang lingkup masalah tertentu.

\section{Obyek Penelitian}

Obyek penelitian ini adalah ketentuan zakat sebagai pengurang pajak di dalam hukum Indonesia.

\section{Sumber Data}

Sebagai penelitian yang berbentuk yuridis normatif, secara umum data yang akan dikumpulkan adalah data yang bersumber dari peraturan perundangundangan dan bahan-bahan kepustakaan baik buku, jurnal, atau media informasi lain. Data yang diperlukan berupa data sekunder atau data kepustakaan dan dokumen yang berupa bahan-bahan hukum sebagai berikut:

a. Bahan hukum primer. Bahan hukum primer adalah bahan adalah bahan hukum yang sifatnya mengikat dan terdiri dari:

1) Undang-Undang Nomor 23 Tahun 2011 tentang Pengelolaan Zakat. 
2) Undang-Undang Nomor 36 Tahun 2008 tentang Perubahan Keempat Atas Undang-Undang No 7 Tahun 1983 tentang Pajak Penghasilan

3) Peraturan Pemerintah Republik Indonesia Nomor 14 Tahun 2014 tentang Pelaksanaan Undang-Undang Nomor 23 Tahun $2011 \quad$ Tentang Pengelolaan Zakat.

b. Bahan hukum sekunder. Bahan hukum sekunder adalah bahan hukum yang menjelaskan bahan hukum primer, yaitu:

1) Hasil-hasil penelitian baik tesis atau disertasi maupun hasil penelitian yang berhubungan dengan hukum zakat dan pajak.

2) Buku-buku, makalah maupun jurnal hukum yang berkaitan dengan hukum zakat dan pajak.

\section{Pembahasan}

\section{A. Zakat Sebagai Pengurang Pajak Pada Periode Undang-undang No. 38 Tahun 1999 Tentang Pengelolaan Zakat}

Undang-undang mengenai zakat pertama kali diundangkan pada tahun 1999, yaitu dengan diundangkannya Undang-undang Nomor 38 Tahun 1999 tentang Pengelolaan Zakat yang disahkan di Jakarta pada tanggal 23 september 1999 oleh Presiden Bacharuddin Jusuf Habibie.

Inilah pertama kali dalam sejarah pemerintah mengatur kaitan antara zakat yang dibayarkan masayrakat sebagai pelaksanaan kewajiban beragaman selain pajak yang dibayarkan kepada negara yang merupakan kewajiban kenegaraan bagi setiap warga negara.
Sebagai landasan pertimbangannya adalah bahwa Republik Indonesia yang menjamin kemerdekaan tiap-tiap penduduk untuk beribadat menurut agamanya masing-masing serta kepercayaannya itu. Sehingga dalam penunaian zakat sebagai kewajiban umat islam indonesia yang mampu. Hasil pengumpulan zakat merupakan sumber dana yang potensial bagi upaya mewujudkan kesejahteraan masyarakat.

Dominannya kewajiban pajak atas kewajiban zakat yang sedemikian rupa telah menjadi persoalan tersendiri. Seperti halnya yang terjadi di negeri kita yang memisahkan hukum positif kenegaraan dengan hukum agama. Sistem penerimaan dalam kebijakan fiskal negara didasarkan pada pajak, bukan zakat, sehingga kaum muslimin yang ingin membayar zakat harus menanggung beban ganda.

Hingga akhirnya pemerintah mulai tergerak untuk melakukan campur tangan terhadap kewajiban penunaian zakat yang tidak memberatkan atau memberikan beban ganda terhadap umat muslim di Indonesia. Sehingga lahirlah Undangundang Nomor 38 Tahun 1999 tentang Pengelolaan Zakat.

Pengaturan zakat sebagai kredit bagi Penghasilan Kena Pajak Pertama kali muncul pada Undang-undang Nomor 38 Tahun 1999 Tentang pengelolaan zakat, yaitu pada pasal 14 ayat (3) undangundang tersebut. Pasal tersebut menyatakan:

"zakat yang telah dibayarkan kepada badan amil zakat atau lembaga amil zakat dikurangkan dari laba/pendapatan sisa kena pajak dari wajib pajak yang bersangkutan sesuai dengan perundangundangan yang berlaku”, 
Adapun alasannya adalah untuk menghindarkan para muzakki yang sekaligus menjadi wajib pajak agar tidak terkena beban ganda (double Burden) dan untuk memacu kesadaran para muzakki untuk membayar pajak. Seperti yang disebutkan pada penjelasan pasal tersebut yang menyebutkan: "pengurangan zakat dari laba/pendapatan sisa kena pajak dimassudkan agar wajib pajak tidak terkena beban ganda, yakni kewajiban membayar zakat dan pajak dan kesadaran membayar zakat dapat memacu kesadaran membayar pajak".

Namun demikian, ternyata tidak banyak orang yang mengetahi bahwa sesungguhnya inilah pertama kali dalam sejarah, pemerintah mengatur kaitan antara zakat yang dibayarkan masyarakat sebagai pelaksanaan kewajiban beragama dengan pajak yang dibayarkan kepada negara yang merupakan kewajiban kenegaraan bagi setiap warga negara.

Meskipun dalam undang-undang ini masih terlihat keengganan pemerintah untuk turut campur dalam pengelolaan zakat yang dapat terlihat pada sanksi yang hanya diberikan kepada pengelola zakat saja, sedangkan kepada muzakki itu sendiri tidak ada sangksi yang dapat menjeratnya apabila tidak menunaikan zakat.

Seperti yang dikatakan Abdul Ghofur Anshori, yang menyebutkan bahwa inkonsistensi ini terjadi dimungkinkan oleh dua hal, pertama, karena kesalah pahaman atau ketidakmengertian anggota legislatif terhadap pengertian zakat. Kedua, karena perbedaan pendapat maupun alasan politik tentang seberapa jauh zakat berhak masuk dalam wilayah fiskal kenegaraan.

Pemberlakuan zakat penghasilan sebagai pengurang penghasilan kena pajak jelas akan berpengaruh langsung terhadap penerimaan pemerintah dari sektor pajak. Semakin banyak umat islam yang membayar zakat akan mengakibatkan semakin banyaknya pengurang penghasilan kena pajak. Sehingga apabila penghasilan kena pajak menjadi kecil dengan sendirinya pajak penghasilan yang diterima negara juga mengecil. Padahal saat ini pemerintah justru sedang berupaya memaksimalkan penerimaan dari sektor pajak.

Namun pada saat diberlakukan, terdapat kendala pelaksanaan undangundang No 38 Tahun 1999 yang menyebutkan zakat yang telah dibayarkan kepada badan amil zakat atau lembaga amil zakat dikurangkan dari laba/pendapatan sisa kena pajak dari wajib pajak yang bersangkutan sesuai dengan perundang-undangan yang berlaku, karena pada saat itu UU Pajak Penghasilan yang berlaku pada saat itu masih belum terdapat ketentuan yang mengatur perihal zakat tersebut dan pada saat itu belum terdapat peraturan pelaksananya sehingga hal tersebut tidak bisa dilaksanakan.

Oleh karena itu, kemudian diterapkannya undang-undang pajak yang baru, yaitu Undang-undang No 17 Tahun 2000 yang diberlakukan mulai tahun 2001 tentang perubahan ketiga atas UU Nomor 7 Tahun 1983 tentang Pajak Penghasilan, yang menegaskan bahwa zakat atas pengahsilan yang nyata-nyata dibayarkan kepada Badan Amil Zakat atau Lembaga Amil Zakat yang dibentuk dan disahkan oleh pemerintah dapat dikurangkan atas penghasilan kena pajak dalam perhitungan pajak penghasilan ornag pribadi maupun badan, dan zakat bukan merupakan termasuk obyek pajak bagi penerima zakat 
dan dapat dikurangkan dari penghasilan kena pajak.

Lahirnya Undang-undang No. 38 Tahun 1999 tersebut juga diikuti dengan dikeluarkannya Keputusan Menteri Agama Republik Indonesia Nomor 581 Tahun 1999 tentang Pelaksanaan Undang-undang Nomor 38 Tahun 1999 tentang Pengelolaan Zakat.

Adapun pembentukan resmi Badan Amil Zakat Nasional sekitar 2 tahun kemudian setelah terbentuknya UU zakat, yaitu pada tanggal 17 Januari 2001 dengan Keputusan Presiden Nomor 8 Tahun 2001 sesuai amanat Undang-undang 38 Tahun 1999 tentang Pengelolaan Zakat. Sehingga UU zakat yang dibentuk pada tahun 1999 ini terkatung-katung tanpa bisa terlaksana dengan baik, karena Lembaga resmi yang bertugas mengelola zakat terbentuknya beberapa tahun kemudian. Sesuai dengan isi dari Keputusan Presiden Nomor 8 Tahun 2001 tersebut, BAZNAS adalah lembaga resmi dari pemerintah untuk melakukan pengelolaan zakat secara nasional, adapun yang dimaksud dengan pengelolaan zakat ini adalah kegiatan perencanaan, pengorganisasian, pelaksanaan, dan pengawasan terhadap pengumpulan dan pendistribusian serta pendayagunaan zakat.

Permasalahan berikutnya adalah pada undang-undang zakat tersebut tidak menyebutkan bahwa zakat yang dimaksud hanyalah zakat atas penghasilan yang dapat dikurangkan dari penghasilan kena pajak.

Setelah undang-undang pajak yang baru (UU No. 17 tahun 2000) tersebut disahkan dan Pembentukan Badan Amil Zakat Nasional dibentuk secara resmi kemudian peraturan pelaksanaannya dituangkan dalam Keputusan Dirjen Pajak Nomor KEP-163/PJ/2003 tentang Perlakuan Zakat atas Penghasilan dalam Perhitungan Kena Pajak Penghasilan, dimana dalam Peraturan tersebut disebutkan bahwa zakat sebagai pengurang penghasilan kena pajak adalah zakat atas penghasilan.

Hal ini terdapat pada pasal 1 ayat (1) KEP-163/PJ/2003 yaitu zakat atas penghasilan yang nyata-nyata dibayarkan oleh Wajib Pajak Orang Pribadi dalam negeri pemeluk agama Islam dan atau Wajib Pajak badan dalam negeri yang dimiliki oleh pemeluk agama Islam kepada Badan Amil Zakat atau Lembaga Amil Zakat yang dibentuk atau disahkan oleh Pemerintah sesuai Ketentuan Undangundang Nomor 38 Tahun 1999 tentang pengelolaan zakat, boleh dikurangkan dari penghasilan bruto Wajib Pajak badan atau penghasilan neto Wajib Pajak orang pribadi yang bersangkutan dalam menentukan besarnya Penghasilan Kena Pajak.

Kemudian pada ayat (2) berbunyi penghasilan sebagaimana dimaksud pada ayat(1) adalah penghasilan yang merupakan objek pajak yang dikenakan Pajak penghasilan yang tidah bersifat final, berdasarkan ketentuan pasal 16 ayat (1) atau ayat (2) undang-undang pajak penghasilan. Kemudian megenai besaran prosentase zakat yang dapat dikurangkan dari penghasilan kena pajak diatur dalam ayat (3) yang menyebutkan besarnya zakat yang dapat dikurangkan dari Penghasilan Kena Pajak adalah sebesar 2,5 \% (dua setengah persen) dari jumlah penghasilan sebagaimana dimaksud dalam ayat (2).

Pada tahun 2010 disahkan Peraturan Pemerintah Nomor 60 Tahun 
2010 tentang Zakat Atau Sumbangan Keagamaan Yang Sifatnya Wajib dapat Dikurangkan dari Penghasilan Bruto yang menyatakan zakat atau sumbangan wajib keagmaan dapat digunakan sebagai salah satu faktor pengurangan Penghasilan Kena Pajak yang kemudian diikuti dengan dikeluarkannya Peraturan Menteri Keuangan Nomor 254/PMK.03/2010 tentang tata cara pembebanan zakat atau sumbangan keagamaan yang sifatnya wajib yang dapat dikurangkan dari penghasilan bruto yang mengatur tata cara perhitungan pengurangan penghasilan kena pajak dengan pembayaran zakat.

Berdasarkan uraian diatas, awal mula pengaturan zakat sebagai pengurang pajak, dengan mekanisme zakat sebagai pengurang pajak penghasilan dimulai pada tahun 1999 dengan disahkannya UU nomor 38 tahun 1999, namun belum bisa terlaksana dengan baik karena UU pajak belum mengatur hal tersebut, sehingga UU pajak yang baru diundangkan pada tahun 2000, diikuti dengan pembentukan BAZNAS pada tahun 2001, dan dikeluarkannya peraturan pelaksana zakat sebagai pengurang penghasilan kena pajak yaitu Keputusan Dirjen Pajak Nomor KEP163/PJ/2003, lalu pada tahun 2010 dikeluarkan peraturan pemerintah nomo 60 tahun 2010 yang menegaskan zakat dapat digunakan sebagai pengurang pajak penghasilan diikuti dengan peraturan Kementrian keuangan yang nomor 254/PMK.03/2010 yang mengatur tata cara pembebanan zakat sebagai pengurang pajak.

Berdasarkan uraian di atas dapat di inventarisasikan secara urut sejumlah peraturan sebagai berikut:
1) Undang-undang 38 Tahun 1999 tentang Pengelolaan Zakat

2) Keputusan Menteri Agama Republik Indonesia Nomor 581 Tahun 1999 tentang Pelaksanaan Undang-undang Nomor 38 Tahun 1999 tentang Pengelolaan Zakat

3) Undang-undang Pajak No. 17 Tahun 2000 tentang Perubahan Ketiga Atas UU Nomor 7 Tahun 1983 tentang Pajak Penghasilan.

4) Keputusan Dirjen Pajak Nomor KEP163/PJ/2003 tentang Perlakuan Zakat Atas Penghasilan dalam Penghitungan Penghasilan Kena Pajak Pajak Penghasilan

5) Peraturan Menteri Keuangan Nomor 254/PMK.03/2010 tentang Tata Cara Pembebanan Zakat atau Sumbangan Keagamaan yang Sifatnya Wajib yang dapat Dikurangkan dari Penghasilan Bruto.

6) Peraturan Dirjen Pajak Nomor PER6/PJ/2011 tentang Pelaksanaan Pembayaran dan Pembuatan Bukti Pembayaran Atas Zakat Atau Sumbangan Keagamanaan yang Sifatnya Wajib yang dapat Dikurangkan dari Penghasilan Bruto (sebagai pengganti KEP-163/PJ/2003)

\section{B. Zakat Sebagai Pengurang Pajak Periode UU No. 23 Tahun 2011 Tentang Pengelolaan Zakat}

Saat ini Undang-Undang No. 38 Tahun 1999 tentang Pengelolaan Zakat sudah digantikan oleh undang-undang zakat yang terbaru yaitu Undang-undang No. 23 Tahun 2011 tentang Pengelolaan Zakat. Secara garis besar tidak ada perubahan yang berarti pada undangundang ini yang mengatur mengenai zakat 
sebagai pengurang pajak. Pengaturan mengenai zakat sebagai pengurang pajak mengalami perubahan posisi, yang sebelumnya berada di pasal 14 (UU No. 38 Tahun 1999 menjadi berada pada pasal 22 sampai dengan 23). Demikian juga halnya dengan bunyinya yang berubah lebih sederhana. Pada pasal 22 menyatakan bahwa:

"zakat yang dibayarkan oleh muzakki kepada BAZNAS atau LAZ dikurangkan dari penghasilan kena pajak."

Selanjutnya pada pasal 23 ayat (1) menyatakan bahwa: " BAZNAS atau LAZ wajib memberikan setoran bukti zakat kepada setiap muzakki"

Yang kemudian pada pasal 23 ayat (2) menyebutkan bahwa "bukti setoran zakat sebagaimana dimaksud pada ayat (1) digunakan sebagai pengurang penghasilan kena pajak"

Berdasarkan bunyi pasal diatas memang berbeda bunyi klausulnya, namun secara garis besar hubungan zakat dengan pajak masih tetap sama tidak mengalami perubahan, yakni masih sebagai pengurang Pendapatan Kena Pajak (PKP).

Diantara aspek terpenting dalam undangundang zakat yang terbaru ini dibandingkan dengan Undang-undang sebelumnya adalah, Pertama, superordinasi dari Badan Amil Zakat Nasional (BAZNAS). Badan ini merupakan satusatunya badan yang memiliki kewenangan atas pengelolaan zakat secara nasional. Bahkan lembaga ini merupakan "Lembaga Pemerintah nonstruktural yang bersifat mandiri dan bertanggung jawab kepada Presiden melalui Menteri”.

Sedangkan Lembaga Amil Zakat (LAZ) yang ada hanyalah merupakan orang yang membantu BAZNAS dalam pengelolaan zakat. Dinyatakan dalam pasal 17, bahwa untuk membantu BAZNAS dalam pelaksanaan pengumpulan, pendistribusian, dan pendayagunaan zakat yang dilakukan oleh BAZNAS, masyarakat dapat membentuk LAZ.

Kedua, masuknya unsur pidana dalam undang-undang yang baru ini. Dalam undang-undang ini berbagai bentuk tindakan terkait zakat dapat dikenai sanksi pidana. Di samping tindakan melakukan pengelolaan yang tanpa izin, juga penyalahgunaan dalam pengelolaan aset zakat juga dapat dikenai dengan sanksi pidana, baik denda maupun kurungan penjara. Pasal 37 sampai 42 tentang pidana karena penyalahgunaan zakat, termasuk melakukan pengelolaan tanpa izin dari yang berwenang.

Undang-undang pajak sendiri juga mengalami perubahan yang kesekian kalinya pada tahun 2008, yaitu dengan UU Nomor 36 Tahun 2008 tentang Perubahan Keempat Undang-undang Pajak Penghasilan. Secara garis besar tidak ada perubahan yang berarti yang membahas mengenai zakat sebagai pengurang pajak maupun sebagai pengurang Penghasilan Kena Pajak.

Namun, kalau kita cermati lebih mendalam, "kerelaan" pembuat UU Pajak Penghasilan ini patur dipertanyakan, karena ketentuan diperbolehkannya pengurangan zakat dari Penghasilan Kena Pajak dimasukkan dalam Pasal 9 UU PPh bukan pada Pasal 6 UU PPh. Pasal 9 UU $\mathrm{PPh}$ adalah pasal yang mengatur mengenai hal-hal yang tidak boleh dikurangi dari PKP. Zakat hanya dimasukkan sebagai "excuse". Seharusnya ketentuan ini dimasukkan dalam pasal 6 UU PPh, karena pasal ini yang secara "khusus" mengatur 
mengenai hal-hal apa saja yang boleh dikurangi dari Pendapatan Kena Pajak.

Peraturan pelaksana Undangundang Zakat ini sendiri disahkan pada tahun 2014 dengan Peraturan Pemerintah Nomor 14 Tahun 2014 tentang Pelaksanaan Undang-undang 23 Tahun 2011 tentang Pengelolaan Zakat. Tidak berbeda jauh dengan Undang-undang zakat sebelumnya, Undang-undang Zakat yang baru ini pun kurang mendapat perhatian pemerintah dan tidak terlaksana dengan baik karena peraturan pelaksananya dikeluarkan beberapa tahun setelahnya, sehingga masih menggunakan peraturan pelaksana undang-undang yang lama. Namun, tidak seperti Undang-undang zakat sebelumnya yang peraturan pelaksanaannya menggunakan Peraturan Menteri Keuangan dan Dirjen Pajak.

Mekanisme pengurangan zakat dari penghasilan bruto ini diatur dalam Peraturan Dirjen Pajak No. PER-6/PJ/2011 Tahun 2011 tentang Pelaksanaan Pembayaran dan Pembuatan Bukti Pembayaran atas Zakat atau Sumbangan Keagamaan yang Sifatnya Wajib yang Dapat Dikurangkan dari Penghasilan Bruto sebagai berikut:

Pasal 2 Peraturan Dirjen Pajak No. PER6/PJ/2011 Tahun 2011:

(1) Wajib Pajak yang melakukan pengurangan zakat atau sumbangan keagamaan yang sifatnya wajib sebagaimana dimaksud dalam Pasal 1, wajib melampirkan fotokopi bukti pembayaran pada Surat Pemberitahuan (SPT) Tahunan Pajak Penghasilan Tahun Pajak dilakukannya pengurangan zakat atau sumbangan keagamaan yang sifatnya wajib.
(2) Bukti pembayaran sebagaimana dimaksud pada ayat (1):

a. dapat berupa bukti pembayaran secara langsung atau melalui transfer rekening bank, atau pembayaran melalui Anjungan Tunai Mandiri (ATM), dan

b. paling sedikit memuat:

1) Nama lengkap Wajib Pajak dan Nomor Pokok Wajib Pajak (NPWP) pembayar;

2) Jumlah pembayaran;

3) Tanggal pembayaran;

4) Nama badan amil zakat; lembaga amil zakat; atau lembaga keagamaan yang dibentuk atau disahkan Pemerintah; dan

5) Tanda tangan petugas badan amil zakat; lembaga amil zakat; atau lembaga keagamaan, yang dibentuk atau disahkan Pemerintah, di bukti pembayaran, apabila pembayaran secara langsung; atau

6) Validasi petugas bank pada bukti pembayaran apabila pembayaran melalui transfer rekening bank.

Menurut Pasal 3 Peraturan Dirjen Pajak No.PER-6/PJ/2011 Tahun 2011 Zakat atau sumbangan keagamaan yang sifatnya wajib tidak dapat dikurangkan dari penghasilan bruto apabila:

a. tidak dibayarkan oleh Wajib Pajak kepada badan amil zakat; lembaga amil zakat; atau lembaga keagamaan, yang dibentuk atau disahkan Pemerintah; dan/atau 
b. bukti pembayarannya tidak memenuhi ketentuan sebagaimana dimaksud dalam Pasal 2 ayat (2).

Pasal 4 Peraturan Dirjen Pajak No. PER-6/PJ/2011 Tahun 2011 menyebutkan:

(1) Pengurangan zakat atau sumbangan keagamaan yang sifatnya wajib sebagaimana dimaksud dalam Pasal 1 dilaporkan dalam Surat Pemberitahuan (SPT) Tahunan Pajak Penghasilan Wajib Pajak yang bersangkutan dalam Tahun Pajak dibayarkan zakat atau sumbangan keagamaan yang sifatnya wajib tersebut.

(2) Dalam Surat Pemberitahuan (SPT) Tahunan Pajak Penghasilan, zakat atau sumbangan keagamaan yang sifatnya wajib sebagaimana ayat (1) dilaporkan untuk menentukan penghasilan neto

Sehingga dapat dikatakan pemerintah mulai serius menaggapi masalah zakat dan pajak ini, yang tiap tahun semakin meningginya antusias masyarakat terhadapnya. walaupun setelah adanya perubahan pada undang-undang zakat tidak membuat zakat dapat mengurangkan pajak secara langsung.

\section{Kesimpulan}

Berdasarkan hasil pembahasan diatas, maka dapat ditarik kesimpulan bahwa Pengaturan zakat sebagai pengurang pajak terbagi menjadi dua periode, pertama periode undang-undang No, 38 Tahun 1999 tentang Pengelolaan Zakat dan kedua, Periode Undang-undang No. 23 Tahun 2011 tentang pengelolaan Zakat. Pengaturan zakat sebagai pengurang pajak pertama kali diundangkan pada tahun 1999 dengan disahkannya Undang-undang No. 38 Tahun 1999 tentang Pengelolaan Zakat. Namun pada periode awal mula pengaturan zakat sebagai pengurang pajak tersebut kurang dapat terlaksana dengan baik karena pada waktu tersebut Undangundang Pajak yang saat itu adalah Undangundang No. 7 Tahun 1983 tentang Pajak Penghasilan masih belum mengakomodir ketentuan zakat sebagai pengurang pajak, sehingga Undang-undang Pajak Penghasilan di ganti dengan Undangundang No. 17 Tahun 2000 yang menegaskan bahwa zakat atas pengahsilan yang nyata-nyata dibayarkan kepada Badan Amil Zakat atau Lembaga Amil Zakat yang dibentuk dan disahkan oleh pemerintah dapat dikurangkan atas penghasilan kena pajak dalam perhitungan pajak penghasilan ornag pribadi maupun badan, dan zakat bukan merupakan termasuk obyek pajak bagi penerima zakat dan dapat dikurangkan dari penghasilan kena pajak.

Sedangkan pada periode kedua, yaitu pada periode Undang-undang 23 Tahun 2011, pengaturan zakat sebagai pengurang zakat lebih tegas dan jelas dari pada periode sebelumnya, karena pada perode ini peraturan-peraturan pelaksana undangundang zakat lebih banyak dikeluarkan dari Peraturan Pemerintah, Peraturan Menteri Keuangan, Peraturan Direktorat Jenderal Pajak untuk mengakomodir ketentuan Undang-undang zakat sebagai pengurang pajak. 


\section{DAFTAR PUSTAKA}

Adrian sutedi, Hukum Pajak, Jakarta: Sinar Grafika, 2011

Agus Triyanta, Hukum Ekonomi Islam, Yogyakarta: FH UII Press, 2012

Ahmad Yani, Seri Praktis Perpajakan, Jakarta: Kencana, 2004

Gazi Inayah, Al-Iqtisad al-Islami az-Zakah wa ad-Daribah, Terjemah, Zainudin Adnan dan

Nailul Falah, Teori Komprehensip Tentang Zakat dan Pajak, Yogyakarta: Tiara Wacana Yogya, 2003

Hikmahanto Juwana, Bunga Rampai Hukum Ekonomi dan Hukum Internasional, Jakarta: Lentera Hati, 2001

Imam Fakhrudin ar-Razi, at-Tafsirul Kabir, Mafatihul Ghaib, al-Matba'ah al-Misrriyah, 1938, XVI

Muhammad, Aspek Hukum Dalam Muamalat, Yogyakarta: Graha Ilmu, 2007

Peter Mahmud Marzuki, Penelitian Hukum, Cetakan Pertama, Jakarta: Kencana, 2005

Rochmat Soemitro, Asas Dan Dasar Perpajakan, Bandung: Eresco, 1990

Soerjono Soekanto, Pengantar Penelitian Hukum, Cetakan Ketiga, Jakarta: UI Press, 2010

Yusuf Qardlawi, Fiqhuz az-Zakah

Undang-undang Nomor 38 Tahun 1999 tentang Pengelolaan Zakat

Undang-undang Nomor 23 tahun 2011 tentang Pengelolaan Zakat

Undang-undang Nomor 7 tahun 1983 tentang Pajak Penghasilan

Undang-Undang Nomor 10 Tahun 1994 tentang Pajak Penghasilan

Undang-Undang Nomor 17 Tahun 2000 tentang Pajak Penghasilan

Undang-Undang Nomor 36 Tahun 2008 tentang Pajak Penghasilan

Peraturan Pemerintah No. 60 Tahun 2010 tentang Zakat atau Sumbangan Keagamaan yang Sifatnya Wajib yang Boleh Dikurangkan dari Penghasilan Bruto

Keputusan Dirjen Pajak Nomor KEP -163/PJ/2003 tentang Perlakuan Zakat atas Penghasilan dalam Perhitungan Kena Pajak Penghasilan

Keputusan Presiden No. 8 Tahun 2001 tentang Badan Amil Zakat Nasional 